\title{
In Celebration of the Life and Work of Donald C. Klein
}

\author{
Preston A. Britner • Martin Bloom • Alan Klein
}

Published online: 12 November 2009

(C) Springer Science+Business Media, LLC 2009

We pay tribute to Donald C. Klein, a pioneer in primary prevention. We remember and celebrate his life and work through the thoughts and reflections of colleagues, family, students, friends, and others.

Don Klein died on June 8th, 2007 at the age of 83, while participating-quite actively, thoughtfully, and influentially, by all accounts-at the biennial conference the Society for Community Research and Action (SCRA; the American Psychological Association's Division 27 for Community Psychology). In various community psychology newsletters and online postings, SCRA leaders and colleagues discussed Don's instrumental role in forming community psychology and moving forward an agenda of "community research and action" at the landmark 1965 Swampscott conference. He served as the organization's 3rd President (1969-1970) and was the recipient of the SCRA Distinguished Practice Award.

Don was viewed as a role model because of his ability to listen to citizens and engage them as equal partners in community change. We have come to understand, over time, that this sort of approach is not only "just" and "appropriate" but it is also instrumental to effective primary prevention. Don's 1977 book (co-edited with Steve Goldston) on "Primary prevention: An idea whose time has come" was groundbreaking and remains a classic. In The Journal of Primary Prevention, Don contributed fascinating and stimulating papers on such topics as a "transforming view of mental health" (1983), "the humiliation dynamic" (1991), and "ending the

P. A. Britner $(\bowtie)$

Human Development \& Family Studies, University of Connecticut, U-2058,

Storrs, CT 06269-2058, USA

e-mail: Preston.Britner@UConn.edu

M. Bloom

Ashford, CT, USA

A. Klein

Columbia, MD, USA 
war on drugs" (2000). His writings are full of thoughtful, provocative, and transformative ideas.

While Don Klein was greatly admired for his extensive contributions to community psychology, primary prevention, the National Training Laboratory (NTL), graduate education at Union Institute and University (Union), community mental health, community development, and human dignity and humiliation studies, among others, we at The Journal of Primary Prevention celebrate his life and work as a rare and authentic human being who could be so productive in life as well as being so loving and caring for his family, his friends, his students, indeed for those who made only a single contact with him at workshops or conferences.

\section{Memorial Reflections}

At a Laurel, Maryland memorial celebration of Don Klein's life and work in August 2007, many colleagues, friends, students, and others came forward to present brief statements on how Don affected them. Don's son, Alan Klein, collected these reflections. We present just a sampling, as there were well over 200 offerings, to attempt to capture in words what these people felt about Don Klein. This is not simply a collage of memories from the past; it is a model for our own future, seeing what one individual can do positively for thousands of people, with whom he came in touch, and for whom the influence will continue to spread.

\section{On His Writings and Their Effects on Others}

"I wrote Don an email after reading his recent book, telling him I had benefited in a specific way, and saying that I was filled with gratitude for my own life but distressed by all the world's problems. He thanked me, and said that he did what he could to make the world a better place, and so did not waste energy worrying about the problems he could not fix..."-Marianna Edgerton

"I was deeply moved and influenced by Don's idea of Projective and Appreciative Psychology, and hope to help in carrying out his ideas and life's work in any way I can."-Neil Ryan Walsh

\section{On Serving as a Teacher and Role Model}

"He was not only one of my great teachers, but a role model on how to live life fully. I admired how he was always open to trying new ways of living in the world, whether it was traveling cross country in an RV, living in an extended family, or exploring new ways to reduce conflict in the world."-Tamara Bliss

"He was a master among masters... expertly enabling and simultaneously challenging. I learned how to see myself in such a vibrant new way through his thorough and vigilant ability to help me explore my world in a multiplicity of holograms."-Phil Gang, Union 
"He was a man of the heart who always sought to have people engage with one another with their hearts fully present so that there could be compassion and respect."-Don and Sherry Penn-Crawford

"You may never know how many lives your Dad touched with his gentle beauty and noble soul. I regard him and Lola [Don's beloved wife who died several years ago] as two of the most influential people in my own life and I will forever by grateful."-John Scott, writing to Alan Klein

"I loved [him] for his authenticity, his wisdom, his humor and the sharing of knowledge and support he so readily gave to me and others when we were new in the field."- Johnnie Smith, NTL

"[He had] a thirst for life and helping people make connections for peace and healing of the world."-Barbie Dossey

"He was a true explorer and bon vivant, an original, a lover, a person who chose to believe the best in people."-Bethe Hagens, Union

"His persistence in pursuit of being himself has always been an inspiration as has his commitment to reconnecting all parts of the body together in keeping the integrity of the whole person."-Charlie Seashore, NTL

"[E]very time I spoke with him I experienced his peace, assurance, insight, knowledge and historical perspective, and genuine caring for individuals and for the health of communities..."-James Dalton

"He did have a rich and full life and multiplied his spirit in so many people that he taught and inspired."-Eileen Paul

\section{On Living and Dying on His Own Terms}

"Dad's passion for appreciating life and those he encountered along the way are but two of his lasting contributions to the world. I hope you will join me in redoubling or efforts to make sure that the world thrives and shines by ensuring that we pay attention to our bottom line and, even more importantly, to our top line, as well. May we all hit the threshold of our 84th birthday living life as fully and vigorously as he did and with his curiosity and thirst to learn new things."-Alan Klein

"I always admired his passion for not only his work, but for living life to the fullest. He was a role model for many of us!"-Sandy Robinson

"Don was a superb fully alive person who cherished every minute of every day."-Larry Ryan, Union

"Nothing like dying while you are engaged in one of your passions." —Victor La Cerva

"It was truly his way-to leave the planet in the midst of serving others. Like countless others, I was privileged to be a recipient of his wisdom and service."Sara Barnes

"With his Cheshire cat grin, dogged groundedness and lucidity, no matter the issue, he was an exceptional man. Yes, his insatiable curiosity and appreciation for life were inspiring. I am heartened that he died as he lived, living his life with zest, and with vision and love in his heart and speech."-Kathleen Daniel

"I must tell you my first reaction was "way to go Don, to go easily and without suffering.' ... 'so happy that you led a full life up to the very end.' - and then, I 
burst into tears. I was holding both feelings simultaneously. I think I was at first happy for him, but then I thought of myself, missing him and realizing what I was losing..."-Libby Baker

[Referring to Don's drumming as part of self definition] "I have no doubt that dear Don is happily drumming with his cosmic buddies... And that he would want us not to mourn, but to continue with the important work which he helped bring into being here on this earth."-Thomas Daffern

\section{On His Personal Characteristics}

"Don was a very important person to me for a lot of reasons not the least of which was his personal authenticity. He was an impressive person to everyone who met and worked with him-but he was never impressed with himself-he was just Don..."-Denny Gallagher, NTL

"To me he was iconic and yet fully human, a combination both rare and admirable."-Steve Putnam, NTL

"[Don Klein] was one of the kindest and yet most brilliant men it has been my privilege to know. He walked his talk and lived life to the fullest, consciously, appreciatively, and with integrity..."-Margaret Tyndall, NTL

"He was a bright light on this planet, and is still a bright star in the firmament of our lives..."-Louise Diamond, NTL

"If I could only live my life with half as much appreciation, interest in people and ideas, integrity, and contribution. I loved him very much!"-Ted Tschudy, NTL

"At almost 84, Don was incredibly energetic, spry, and a gifted intellectual. His company was inviting and welcome. He was inquisitive and interested in everything. He was a passionate advocate for peace. We will miss him dearly."-Michael Osborne, Jane Dembner, \& Daniel Osborne

"Don was the living model of equal dignity for all. He inspired so many of us to strive for goals that we never thought possible. He dared to believe that each of us had something special to contribute to the world and we spent our lives living up to his worlds of wisdom and vision. He was our precious inspirational treasure and our dearest friend. He taught so many of us the pleasure of living life in "awe and wonderment.' We will always carry his legacy of appreciation in our hearts." Linda Harding

\section{Concluding Thoughts}

And so it goes, letter after letter, from people who knew Don Klein over his 50 years of professional life (and some before that), in many different venues, engaging in a variety of different activities. If you can sense the deep feelings of awe, respect, and commitment that he inspired in others, then we will have succeeded in celebrating the life and work of this authentic human being, Don Klein. 